Review scientific article Received 16.02.2018. Approved 21.03.2018.

\title{
COMBINING THE “BELT” WITH THE ROADS AT THE HEART OF EUROPE: GEOPOLITICS OF THE BBSP CORRIDOR
}

This paper discusses the importance of the Budapest-Belgrade-Skopje-Piraeus (BBSP) corridor in the context of the "One Belt, One Road," Initiative (B\&RI), standing as the connecting piece, to serve as a fast transit route, between three major economic corridors. Indeed, the BBSP appears to be the platform that magnifies the true potential of the Belt and Road Initiative in the Western and central Europe. Therefore, the BBSP is particularly decisive for landlocked economies, such as Hungary and Serbia. The BBSP is a brick on a larger wall when we refer to the cooperation between China and Central and Eastern European Countries. But it is certainly an important one, especially because it delivers flexibility to the network of economic agents. Finally, this paper adopts a geopolitical perspective, grounded in geo-economics concepts.

Keywords: BઐRI, People’s Republic of China, COSCO, Geopolitics, Serbia, Hungary, Piraeus, Europe, Eastern European Countries

City University of Macau-China; franciscoleandro@cityu.mo 


\section{Introduction}

B\&RI is "a long-term undertaking." President Xi Jinping

(In May 2017 at first Belt and Road Forum, Beijing, People's Republic of China)

Europeans by default tend to pay attention to the US and often neglect to cast an eye on the new transformers of the international relations picture, the players such as the Russian Federation, the Republic of India and the People's Republic of China. The antics of the Trump Administration, the egocentricity of BREXIT, and the imprudence of the Carles Puigdemont Catalonia regional administration have diverted European public opinion even further away from the latest relevant developments in global policy. Among them stands the "One Belt, One Road" Initiative (B\&RI), put forward by President Xi Jinping in 2013. The first Belt and Road Forum for International Cooperation concluded in Beijing in May 2017, inaugurated a new era of infrastructural realizations, involving cooperation, several agreements, the participation of 29 foreign heads of state and government, representatives from more than 130 countries and 70 international organizations. ${ }^{1}$ Therefore, for the purpose of this article, B\&RI will be discussed as an access strategy, based on infrastructural access connectivity, acknowledging the colossal Chinese efforts to strengthen its economic capacity, based on regional integration, market-oriented reforms, and policies such as "going out" and "coming in". In fact, 2001 marked the moment of economic change, with the China's accession to the World Trade Organization.

Figure 1. The NELB, the CCWAEC and the MSR

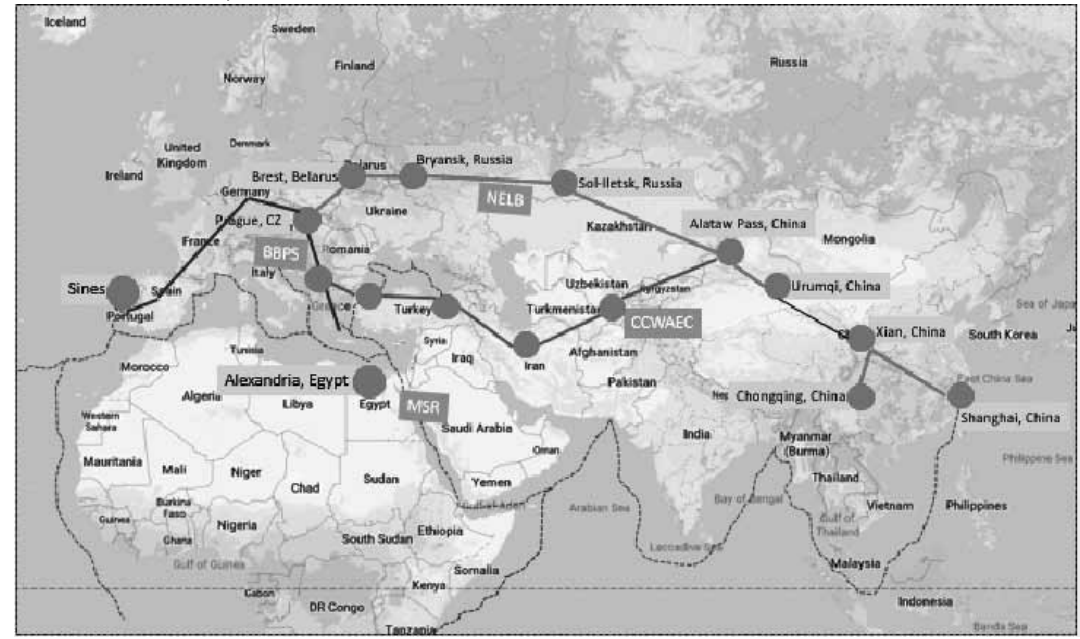

Source: prepared by the author

State Council of PRC: "Belt and Road Forum to bring about fresh ideas", http://english.gov. cn/news/video/2017/05/12/content_281475653319187.htm(02.07.2018). 
Matolcsy $(2017)^{2}$ asserted recently the following: “...but what is this New Silk Road? It encompasses sixty-four countries, including China, two-thirds of the world's population, and currently only 40 per cent of the global GDP... This Silk Road will connect the participants constituting the new, 21st century phase of globalization. It can already be seen that the network of the Silk Road consists of a northern, middle and southern branch. The southern branch is the railway Silk Road. There is a maritime Silk Road which is especially promising". From China's strategic viewpoint, the positioning of the B\&RI land and maritime corridors vested two European areas with vital importance: Belarus-Poland-Ukraine and Turkey-Greece-Serbia-Hungary. In light of this strategy, this paper addresses the geopolitical importance of the Budapest-Belgrade-Skopje-Piraeus (BBSP) (Figure $1 \mathrm{BBSP}$ is represented in yellow color) corridor as the one that closes the loop between the new European land bridge (NELB), the China-Central AsiaWest Asia Economic Corridor (CCWAEC), and the maritime Silk Road (MSR). All three, connect the center of Europe and the Chinese economic heartland. There are other components of the B\&RI relevant to Europe such as the Polar Silk Road, the Arctic Railways (between Rovaniemi and Kirkenes), the transCaspian Railways, the Baku-Tbilisi-Kars Railways or the Sines-Madrid Railways. However, the BBSP geopolitical significance rests with its ability to combine land and maritime economic corridors, to facilitate the trade between the eurozone, Europe and China, and to convey flexibility between the continental and maritime flows of transportation.

\section{Why does the BBSP corridor matter?}

The geopolitical importance of the Budapest (Hungary)-Belgrade (Serbia)Skopje (Macedonia)-Piraeus (Greece) corridor, for the purpose of this paper designated as the BBSP corridor, rests with its ability to connect the NELB running from Urumqi, through Eurasia in direction of Brest (Belarus) and the MSR, running from China's southern coastal areas to the Red Sea and entering into the Mediterranean Sea via the Suez canal. The BBSP defines a transportation axis running in both directions and connecting Southwest Germany, Prague, Bratislava, Budapest, Belgrade, Prǐstina, Skopje, Thessalonica or Piraeus in Greece.Either through the Suez Canal or via the Gibraltar Strait, the sea lines of communication (SLOC) are designed to reach major sea ports into Mediterranean Sea, such as Piraeus-Thessaloniki (Greece), Marseille (France), Benghazi (Libya), Tunis (Tunisia), Livorno-Venice (Italy), and Barcelona (Spain).

GyörgyMatolcsy, Governor of the Central Bank of Hungary: "Hungary - A Key State on the Silk Road", Pageo, Edited Version of the Opening Presentation Delivered at the 54th Annual Meeting of Economists on 15 September 2016,http://www.geopolitika.hu/ en/2017/03/20/hungary-a-key-state-on-the-silk-road/ (02.02.2018). 
The BBSP further represents the segment that closes off the loop, connecting the Chinese heartland to central Europe, by land and sea, facilitating land access to one of the most productive and economically dynamic regions in Europe.

Figure 2. The BBSP

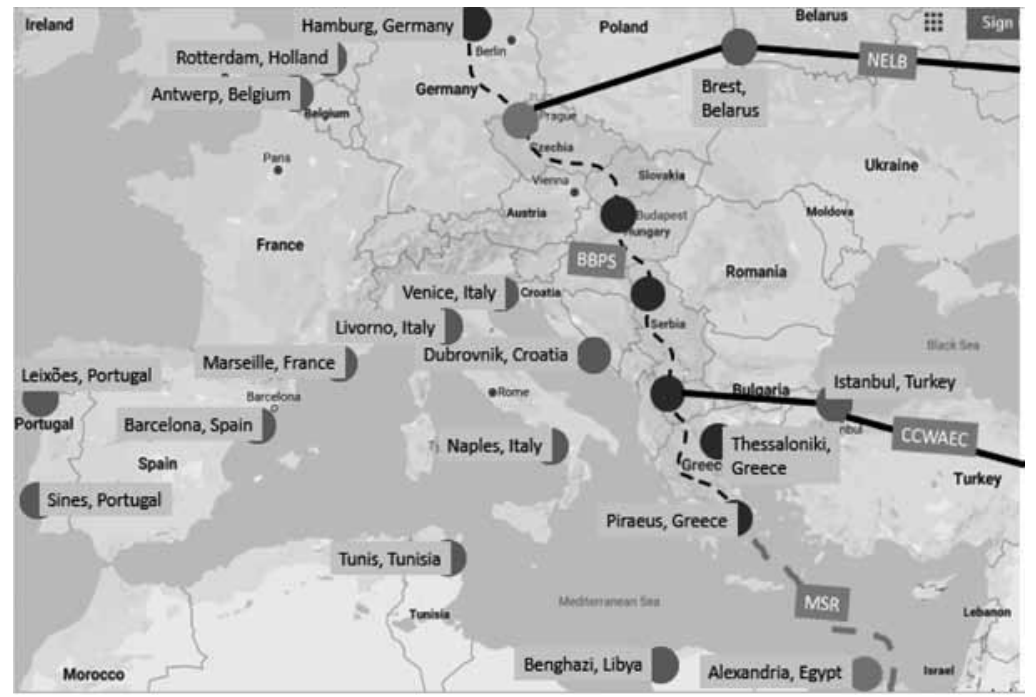

Source: prepared by the author

The idea of this corridor is to create a land-sea express passage composed of a high-speed rail line, alongside special arrangements concluded through customs clearance treaties, trade and investment facilitation settlements, free trade agreements and foreign direct investments. The BBSP has the ability to further develop the trade flow between China and the European Union, taking into consideration that China is already the EU's largest trading partner. In addition, the BBSP holds the potential to advance the development of the so-called Central and Eastern European Countries (CEEC) at regional logistics level, to link the Mediterranean Sea and the Danube River, and to explore the advantages of the future enlargement of the Suez Canal. According to the Suez Canal Authority ${ }^{3}$, the idea is to decrease waiting hours from 18 to 11 hours for most ships and to increase the daily average of transiting vessels to 97 ships by the year 2023, up from 49 ships at present. Apart from the Volga River, the Danube River is the longest river in Europe that flows eastwards across ten countries for 2,850 km. Access to the Danube River facilitates access to Germany, Austria, Hungry, Slovakia, Serbia, Croatia, Romania, Bulgaria, Ukraine, Moldova and represents a complementary water line of communication to the Black Sea as an

Suez Canal Authority, https://www.suezcanal.gov.eg/English/About/SuezCanal/Pages/ NewSuezCanal.aspx (31/08/2018) 
alternative to the SLOC crossing the Dardanelles strait, the Sea of Marmara and the Bosporus strait.

However, the importance of the access to the Danube River goes further. Indeed, Germany (Bavaria) completed the Rhine-Main-Danube Canal in 1992 and its 171 kilometers, allowing the connection between the Main and Rheine Rivers. The Main River is an affluent of the Danube River, and that fact has extended the possibility to navigate from Rotterdam (in the Netherlands) to the Danube Delta in south-eastern Romania and south-western Ukraine (or Constanța (Romania), through the Danube - Black Sea canal). In fact, the Rhine-Main-Danube Canal and the BBSP corridor together connect not only the North Sea and Atlantic Ocean to the Black Sea, but also the major European cities. For the B\&RI that represents simple and easy access to the major European markets and production centers. Put simply, the BBSP combined with access to the Danube and Rhine Rivers, probably signifies one of the most important pieces of the access strategy, which potentiates the B\&R corridors connecting the Xinjiang autonomous province in China and the Chinese coastal zones to the very center of Europe. The BBSP completes the sea-land access between the Chinese production-consuption centre of gravity to the European productionconsuption centre of gravity. The BBSP is currently the missing link between the two most important production-consuption centres of gravity in the world.

Figure 3. The CCWAEC

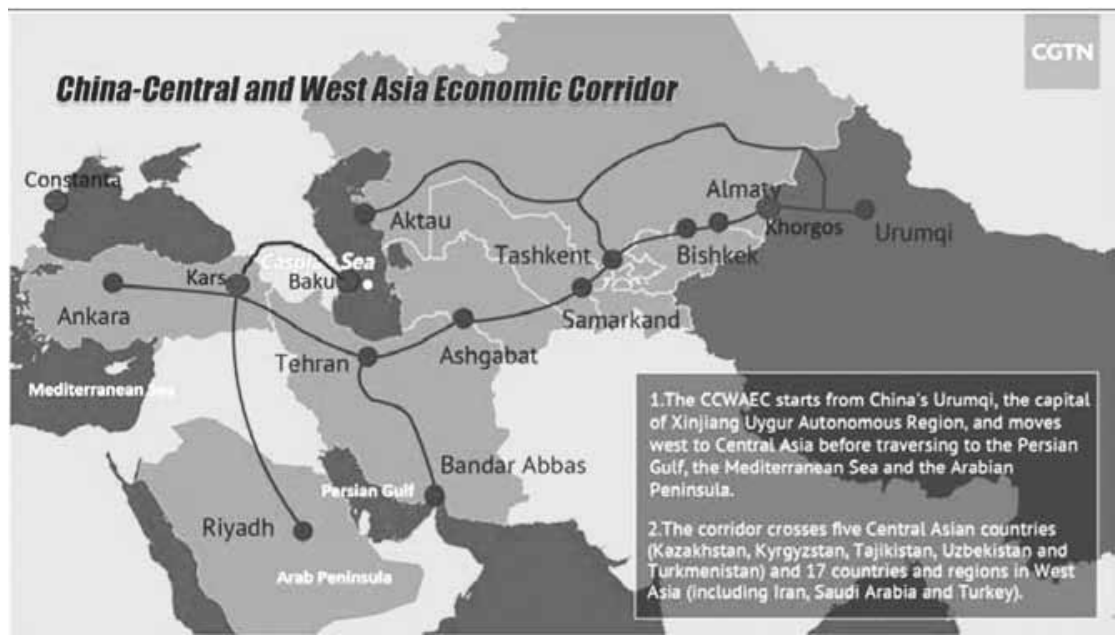

Source: https://news.cgtn.com/news/3349544f31557a6333566d54/share_p.html

The BBSP further complements the corridor Bratislava-Belgrade-SkopijeSofia-Istambul-Ankara that runs into Turkey as a extention of the ChinaCentral Asia-West Asia Economic Corridor (CCWAEC). In fact, the CCWAEC 
links China and the Arabian Peninsula can be extended to Europe, using the BBSP. The CCWAEC runs fromXinjiang (Urumqi) across Central Asia before reaching the Persian Gulf, Arabian Peninsula, and the Mediterranean Sea. It crosses Central Asian countries such as Kazakhstan, Kyrgyzstan, Tajikistan, Uzbekistan and Turkmenistan and countries and regions in West Asia namely Iran, Saudi Arab, Syria and Turkey. In Turkey, the CCWAEC also links up to maritime sea routes across the Black Sea in the direction to Odessa (Ukraine), Constanța (Romania), Varna, and Burgas (Bulgaria). In Iran the CCWAEC also connects to maritime sea routs across the Caspian Sea region. This region is also a sort of pivotal areas in the CCAWAEC, and therefore vital to B\&RI that envisions a route connecting Asia, Europe and the rest of the world. Iran is also important because of its geopolitical ability to link CCAWAEC to the Persian Gulf and to Shatt al-Arab.From this perspective, BBSP is another link giving sense to an entire network of economic corridors.

But what is an economic corridor? We ought to consider the innovative work of Hans-Peter Brunner and Gadzeni Mulenga. According to Brunner ${ }^{4}$, "Economic corridors are not mere transport connections along which people and goods move"; rather, these corridors "connect economic agents along a defined geography. They provide connection between economic nodes or hubs, usually centered on urban landscapes, in which large amounts of economic resources and actors are concentrated. They link the supply and demand sides of markets... Economic corridors are integral to the economic fabric and the economic actors surrounding [them]. Economic corridors [do not generate] significant economic benefits in isolation, but rather they have to be analyzed as part of integrated economic networks, such as global and regional value chains and production networks". It appears from the cases this author analyzed that economic corridors are geographically co-located sets of mechanisms to facilitate interaction between economic agents. It also seems important to understand that they do not exist in isolation but have a regional development role, 'comprehended only in terms of the network effects that they induce'. Brunner ${ }^{5}$ further demonstrates that there is "no standard picture of what economic corridor development is and what it can achieve. What economic corridors can achieve for regional economic integration depends first on what characteristics the specific existing economic networks in which the economic corridors are embedded personify, and second on which characteristics corridor development are intended to introduce or strengthen. Corridor characteristics interact dynamically to create patterns of regional economic development". Mulenga puts forward two important aspects of the concept of economic corridors: corridor characteristics and the different

4 Hans-Peter Brunner (2013): What is Economic Corridor Development and What Can It Achieve in Asia's Sub-regions? Asian Developing Bank Working Paper Series on Regional Economic Integration, Manila, Philippines, No. 117, 9

5 Ibid. 
stages of corridor transformation. In relation to their general characteristics, Mulenga ${ }^{6}$ emphasizes the following: "A smaller, defined geographic space, usually the area straddling a central transport artery such as a road, a rail line, or a canal; Bilateral rather than multilateral initiatives focusing on strategic nodes, particularly border crossings between two countries, principally to promote a sense of ownership; An emphasis on physically planning the corridor and its surrounding area, to concentrate infrastructure development and maximize benefits; and strong public-private partnerships, which promote sustainability". Again, the concept of an economic corridor seems to be associated to the idea of co-location of access infrastructures and trade facilitation mechanisms. Mulenga $^{7}$ goes further to say that there are four stages in the development of an economic corridor: (1) the physical development ${ }^{8}$; (2) the logistics development ${ }^{9}$; (3) the economic and social development ${ }^{10}$; and (4) the integration of crosscutting issues ${ }^{11}$. Once again we can observe the centrality of infrastructure, at the very beginning of the physical development. Brunner ${ }^{12}$, discussing the evaluation of economic corridors, observed: A comprehensive assessment of economic corridor performance over time for investment and policy decisions requires

6 GadzeniMulenga (2013): Developing Economic Corridors in Africa: rationale for the participation of the African Development Bank, AfDB Regional Integration Brief, NEPAD, Regional Integration and Trade Department, No. 1, Tunisia, 2.

7 Ibid.

8 This involves enhancing the physical facilities needed for efficient and effective transportation and trade by establishing and revamping transport links; improving the quality of infrastructure, increasing carrying capacity, and dealing with related safety issues; upgrading infrastructure associated with priorities such as rural agriculture, agroindustry, and tourism; encouraging multimodal structures; and upgrading border areas.

9 The right logistics can harmonize corridor policies, regulations and institutions, moving people and goods more efficiently and facilitating storage, warehousing, trucking, insurance and freight management, and related services. Good logistics also involve implementing cross-border trade agreements; simplifying, standardizing and harmonizing immigration and quarantine procedures; promoting information and communication technologies; and establishing logistics centres.

10 This stage promotes investments in areas such as agroindustry and manufacturing, natural resource-based enterprises, small-scale industries, trade (including planned roadside shops), tourism (rest houses and hotels), schooling, and health facilities, all located near the corridor. Other interventions might include the promotion of innovative trade techniques such as fair trade products and investment forums, again close to the corridor. The economic and social development stage might also market business opportunities in key industries; establish special economic zones where appropriate; publicize investment policies, rules and regulations; offer micro-financing; adopt special measures for approving business licences efficiently and effectively; and address other infrastructural deficiencies, such as inadequate water and power.

11 This stage addresses environmental and institutional capacity concerns and other social issues.

$12 \quad$ Ibid, 17.

Vol. 15, № 3, 2018: 207-224 
data along three parameters: (i) the geographic location-bound availability of economic resources, including human resources, natural resources, capital and financial resources, and physical resources such as infrastructure; (ii) movements over time of people, including their services, and goods (mobility of resources) - these movements have a time and economic cost dimension; and (iii) the developing relationships of economic resources over time and through space, and the changing density of their interactions, interaction reliability, and quality. Once again, it appears that the concept of economic corridors rests with the co-location of infrastructures and resources designed to facilitate the creation of a trans-border trade network within a geographical area. It is usual to link this infrastructure to high-speed rail lines, power plants, highways, pipelines, logistics centers, industrial parks, logistical hubs, bridges, airports, power lines, social infrastructures, seaports and cross-border economic zones.

The BBSP is designed to make possible the linkage between supply and demand sides of markets, decreasing the travel time between the Serbian and Hungarian capitals down from eight to three hours, and facilitating the movement of goods from the Greek port of Piraeus into the heart of Europe. Generally speaking, waterways are the cheapest means of transportation, railway and road (land) are both four times more expensive than waterways, and air freight is four times more expensive than land transportation. According to Freightos (2018) ${ }^{13}$ "Simply put, air freight comes with a hefty price tag. Comparing air and ocean freight, a medium size 2,000 lbs. box from Shenzhen, China to New York, US, can cost $\$ 1,200$ by ocean but a whopping $\$ 4,000$ by air". That matters for any sort of access strategy, and therefore matters to B\&RI as it relays mainly in shipping and rail freight. However, the BBSP cannot be mistakenly taken as one more economic corridor, similar to NELB, as the concept lies with the co-location of infrastructures and resources designed to facilitate the creation of a trade transborder network within a geographical area. Therefore, in a regular approach to the economic corridor concept, this physical network, with a central transport artery, is to be complemented with a number of different arrangements, namely through customs clearance treaties, promotion of two-way investments, trade and investment facilitation settlements, free trade agreements and foreign direct investments, visa bilateral agreements, transportation agreements and standardized technical memorandums, special economic zones, tax exemptions, special tax regimes, dispute settlement mechanisms, and handling technical agreements. In the case of BBSP, we are talking about a land-sea express passage composed of a high-speed rail line (the central infrastructure) and not, at least for the time being, a geographically co-located set of mechanisms to facilitate the interaction between economic agents as part of a cross-border network. Perhaps it will be developed like that in the future, but that would be difficult due to the

13 Freightos: "International Air Freight Explained: Air Freight Charges, Rates\& Costs", https://www.freightos.com/portfolio-items/air-freight-rates-cost-prices/ (27.02.2017) 
fact that Greece and Hungary are European Union member states, but Serbia and Macedonia are not. Actually, Macedonia has been a candidate for accession to the European Union since 2005, but has not yet entered into accession negotiations. Serbia initiated a Stabilization and Association Agreement (SAA) with the European Union in 2007, but since 2014, the political support for accession among Serbian population has dropped significantly.

The sea-land connectivity requires deep water sea ports. Hence the importance of Piraeus grew in the context of B\&RI, since the Hong Kong Chinese Ocean Shipping Company (COSCO) purchased a 35-year concession to upgrade and run two container cargo piers and transform Piraeus into a regional hub for sea trade with Europe. The poor performance of the Greek economy has turned into an asset to identify Greece as a valuable partner to China. On the top of this, it also worth mentioning the importance of the Greek commercial fleet and the opportunities offered by the Chinese shipyards, especially by the state-owned company Fujian Shipbuilding Trade Company.

Figure 4. The BBSP and the Rivers Rhine and Danube

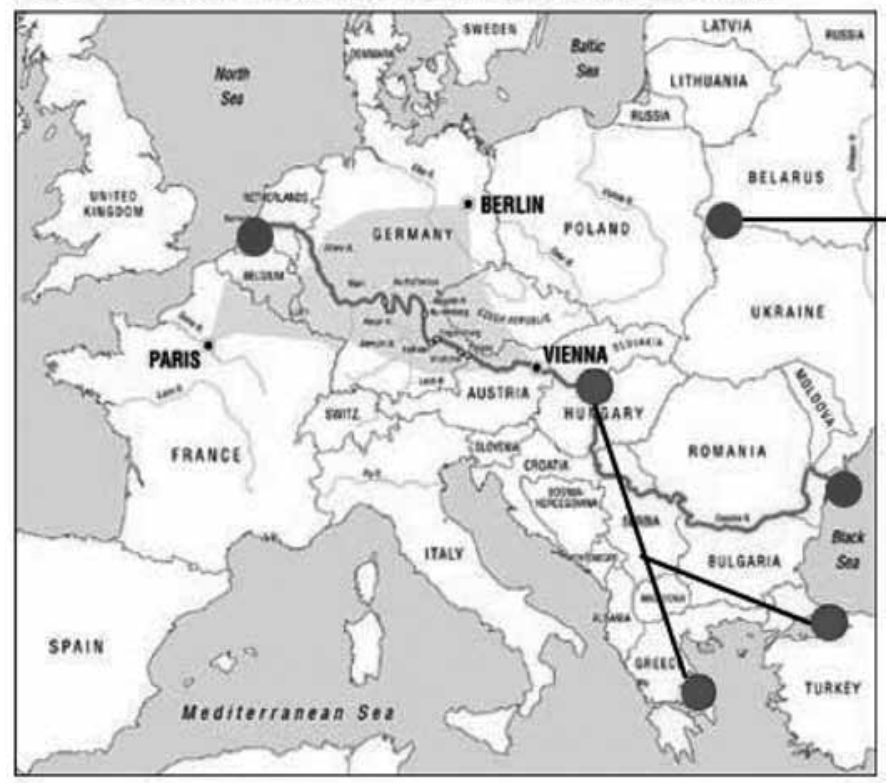

Source: http://www.schillerinstitute.org/economy/maps/maps3.html

COSCO has been operating the Greek container port since 2008, and in 2017 acquired $67 \%$ of its shares. Piraeus is no longer a sleepy and unproductive infrastructure, it has been transformed into a promising investment whose success also depends greatly on its land connectivity. The acquisition of the Port of Piraeus is an important piece within the B\&RI, but is not a single move 
strategy. Piraeus needs the BBSP as much as the BBSP needs Piraeus. Indeed, the objective is to transform the Port of Piraeus into the largest port of the Mediterranean region by 2020, by using the synergies which will result from the Chinese development of other sea ports all the way in the MSR, namely in Sri Lanka (Hambantota), Pakistan (Gwadar), Myanmar (Sittwe and Kyaukphyu), Djibouti (Doraleh), Bangladesh (Chittagong), Kenya (Mombasa), Tanzania (Mtwara) and Mozambique (Beira).

At this stage it is necessary to recall that according to the International Chamber of Shipping (2017) $)^{14}$ around $90 \%$ of world trade is carried by the international shipping industry, almost $40 \%$ of global liquefied natural gas trade moves through the South China Sea ${ }^{15}$, more than 10 percent of world trade sails through the Red Sea basin ${ }^{16}, 95 \%$ of EU Member States' trade (by volume) is transported by sea, and $20 \%$ of global trade passing through the Gulf of Aden ${ }^{17}$. That is why the port of Piraeus, and perhaps the port of Thessaloniki, fit into this system of maritime and land corridors. This fact is extremely important because Piraeus-Thessaloniki gives sense to the BBSP, and therefore it would connect the maritime and continental sections of the Silk Road. Particularly interesting are the geopolitical features of European landlocked states such as Hungary and Serbia, located between the Black and the Adriatic Sea, between the Carpathian Mountains and the Dinaric Alps. Their functional advantage lies in the fact that they are both rotational platforms for goods transported either by railway or waterway. In Belgrade, two important international rivers (the Danube-Tisza and the Sava) flow to facilitate the regional exchange of goods and services, combining their potential with a high-speed rail line, BelgradeBudapest and Belgrade-Skopje. According to Dimitrijevićn "China is a very good economic partner of Serbia in Asia and one of the major pillars of Serbia's foreign policy... Serbia is one of China's key partners in the region of Southern and Eastern Europe. China primarily sees the Southern and Eastern Europe in terms of economic integration with the European Union as a common market of high purchasing power and therefore an ideal space for the placement of its own products. In this regard, it is important to note that China supports Serbia's aspirations for full accession to the European Union, without prejudice to its

$14 \quad$ International Chamber of Commerce: "Shipping and World Trade", http://www.ics-shipping.org/shipping-facts/shipping-and-world-trade (25.08.2018)

15 US Energy Administration Information, "Almost $40 \%$ of global liquefied natural gas trade moves through the South China Sea",https://www.eia.gov/todayinenergy/detail. php?id=33592 (25/01/2018)

16 Fahd Al Rasheed, "Red Sea - artery of global trade", from http://www.arabnews.com/columns/news/879221(25/01/2018)

17 EUNAVFOR,http://eunavfor.eu/mschoa/ (20/03/2018)

18 Duško Dimitrijević (2017): Chinese Investments in Serbia - A Joint Pledge for the Future of the New Silk Road, Institute of International Politics and Economics, Baltic Journal of European Studies, Tallinn University of Technology, Vol. 7, No. 1, (22) 68. 
vital national interests". In a paper published by the Baltic Journal of European Studies in 2017, Dimitrijević1 ${ }^{19}$ mentioned the following:

"In actual Serbian foreign policy strategy, China occupies an important place. The strategy is designed on four pillars of foreign policy. The first pillar is the European Union whose member Serbia would like to become. The second pillar is Russia as arising power in world politics and Serbia's historical partner. The third pillar is the United States, as a great power with whom Serbia has had fluctuating relations in the past, but whose importance and influence in international relations Serbia has accepted as a reality. The fourth important pillar of Serbia's foreign policy strategy is China as a global economic power and the traditionally good friend of Serbia in international relations. (Dimitrijević \& Jokanović, 2016b, p. 328)"

The Sino-Serbian strategic partnership established in 2009 and reinforced in 2013 with a joint statement signed by the Head of State Tomislav Nikolić and $\mathrm{Xi}$ Jinping, are the visible face of the joint interests shared by Serbia and China. Serbia has also established a strategic partnership with the Russian Federation in 2013. It is necessary to bear in mind that People's Republic of China has always expressed diplomatic proximity to the Serbian Government in relation to the Kosovo affair, and that fact facilitates the development of bilateral relations in different areas. Therefore, railways are not the only infrastructures in the center of the Sino-Serbian relations, but all of them are to a certain extent related to the access strategy. Extraordinary loans, new bridges, new highways, airport cooperation, power plants restructuration, telecommunications, national power grid development are sounding examples of this promising cooperation. According to See News (Business Intelligence for South East Europe), Serbian infrastructure minister Zorana Mihajlovic signed in Beijing (July 2017) two memoranda of understanding (MoU) with China Road and Bridge Corporation (CRBC) for infrastructure works with a combined value of 2.5 billion euro. The contracts are for the construction of the Preljina-Pozega and Pozega-Boljare stretches of a motorway which will connect Belgrade to the border with Montenegro, and Fruskogorski Corridor, a $123 \mathrm{~km}$-long road in Serbia's Vojvodina autonomous province ${ }^{20}$.

Ibid.

20 SeeNews: "China's infrastructure investments in Serbia reach 5.5 billion euro", https:// seenews.com/news/chinas-infrastructure-investments-in-serbia-reach-55-bln-euro-serbian-govt-572427 (10/02/2018) 
According to Teokarevic ${ }^{21}$, "Serbia desperately needs China's capital and know-how to improve its infrastructure. There are two main reasons for this: a very poor transport and energy infrastructure that has not been properly renovated for decades, and the lack of necessary investment in this area by its other main partners, the EU and Russia". Nevertheless, the three key Serbian partners appear to be the European Union (trade partner), the Russian Federation (trade partner) and People's Republic of China (political partner). Teokarevic ${ }^{22}$ also mentioned the following: "Nevertheless, the "special relations" with Russia and China have great importance for a small country like Serbia, which has managed, unlike its neighbors in the region, to become a strategic partner of two big and powerful countries. In times of economic crisis, diversification of economic cooperation is essential, and Serbia feels that its relationship with Russia and China is a move in the right direction". The Sino-Serbian bilateral ties are likely to develop even further in the next decade, expanding to others areas of cooperation, namely to the defense and the security.

Figure 5. The Serbian Platform

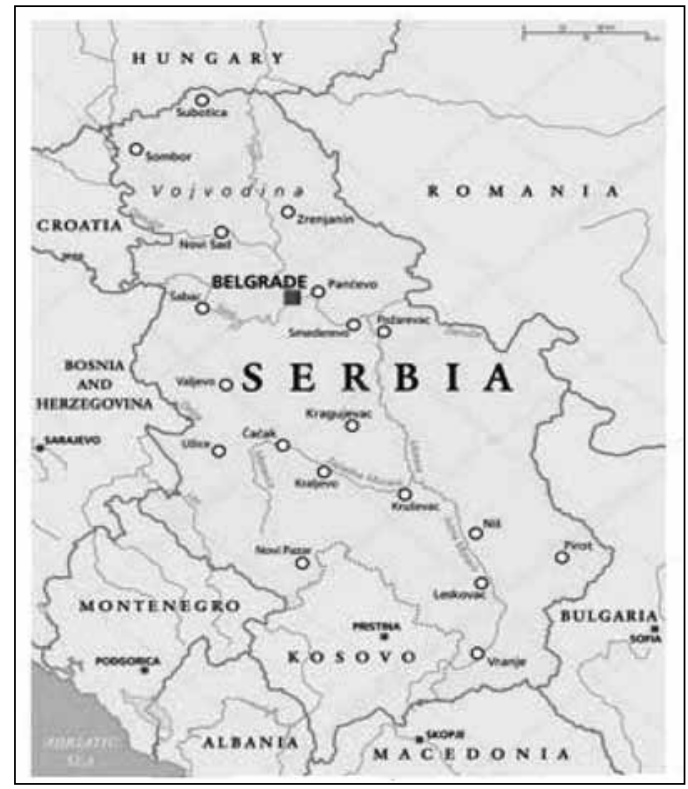

Source: https://depositphotos.com/83815156/stock-ilustration-serbia-political-map.html

$21 \quad J o v a n$ Teokarevic(2016): “Serbia: Perspectives on Eurasian integration”, European Council on Foreign Relations, https://www.ecfr.eu/article/essay_eurasian_integration_serbia $(31 / 08 / 2018)$

$22 \quad$ Ibid. 
The continuum of improving relations between China and Hungary has resulted in a significant increase of Hungarian trade sales to China. Hungary and China signed a memorandum of understanding over the Belt and Road Initiative in 2015. In 2017 Hungary and China established a comprehensive strategic partnership between the two countries. Moreover, Hungary was the first European country to establish the Belt and Road working group mechanism with China. Hungary has actively participated in the China-CEE Investment Cooperation Fund. In fact, Budapest is located not far from the heart of European Union, the German markets, and the industrial centers in Poland. Hungary has land borders with seven countries: Austria, Slovakia, Romania, Ukraine, Serbia, Croatia, and Slovenia. Moreover, the quadrilateral perspective Budapest-Bratislava-ViennaZagreb offers an interesting logistics platform, considering the challenges of mountainous terrain. Actually, the Budapest-Belgrade plain is surrounded by the Alps, the Balkan and the Carpathian Mountains which are the last obstacle to access the northern European plain were Germany and Poland are located. The $350 \mathrm{~km}$ high-speed rail line from Belgrade to Budapest (length on the Serbian side is $184 \mathrm{~km}$ and on the Hungarian side is $166 \mathrm{~km}$ ) has no other track option due to the geography and the distribution of markets and production centers. The high-speed rail lines are to be connected to the China-run Piraeus port in Greece giving BBSP its full purpose. Consequently, the Hungary plain is a natural access corridor from the Mediterranean Sea to northern Europe. Bearing in mind the landlocked position of Hungary (and Serbia) and recalling the words of Eszterhai ${ }^{23}$ " ... it is the interest of the CEE Region and Hungary that the $\mathrm{B} \& \mathrm{R}$ connects rather than separates the EU and China, in which the CEEC fulfil the role of some kind of a bridge", their geopolitical role in the B\&RI context is expected to be an articulated land platform to access markets and production centers, working in both directions - in and out.

The Governor of Central Bank of Hungary Matolcsy ${ }^{24}$ in 2017, put forward the reasons why Hungary is a key country in the context of B\&RI initiative?

"There are several reasons for this. For example, the fact that we are close to the heart of the EU, the German market and a Central European economic hub is really evolving, as Poland is considered one in the north. The Central Bank of Hungary has already taken the first steps on the Silk Road. We established effective cooperation with one of the largest financial institutions of the world, the Bank of China. After the United Kingdom, we were second to sign an agreement with the People's Bank of China - China's central bank

$23 \quad$ Viktor Eszterhai(2017): “The One Belt One Road from Germany's perspective”, http:// www.geopolitika.hu/en/2017/08/15/the-one-belt-one-road-from-germanys-perspective/ $(31 / 08 / 2018)$

24 Ibid.

Vol. 15, № 3, 2018: 207-224 
- and since then we have been using a lot of creative, innovative instruments within this framework. We want to understand what steps they take and why, and we want to take part in this process".

To end with a note in relation to Hungary we should bear in mind that it is vital the success of Hungarian BBSP railway section, as it will be the first time that Chinese corporations will be building a railway within the EU territory. Actually, that fact could set a precedent in relation to future infrastructural developments in the EU with Chinese participation. According to Nikolić ${ }^{25}$, the CEEC geographic position and market capacities represented important "regional potential" for "One Belt, One Road" initiative's implementation. These countries already enjoy good political relations with China, accompanied by mutual trust and deepened practical cooperation". The mechanism for ChinaCEEC cooperation (China+16) was established in Warsaw (Poland) in 2012 as a framework supposed to facilitate growing cooperation in the areas of energy infrastructure, agriculture, science, education, culture and tourism, as well as faster construction of "Silk Road Economic Belt". Consequently, the agreements signed in Bucharest in 2013 at the meeting between China and the CEEC are the rational result of a geopolitical analysis. In spite of the concerns raised by the European Union in relation to Hungary, due to potential infringements of the European Union's public tender requirements for large-scale infrastructure projects, we all recognize the BBSP as vital for the Serbia-Hungary axis. Thus, we believe that BBSP participation requires a common strategy to B\&RI, since itis an unavoidable initiative for Hungary, Serbia and the European Union.

\section{Conclusion}

We believe it is the right time to pay more attention to all issues involving China with special emphasis to those concerning China and Europe. It is time to write more, debate more and study Chinese related issues. B\&RI is becoming increasingly important at regional and interregional level, and it deserves a greater deal of attention, especially in the areas involving European states encompassing the maritime and land dimensions. Sooner or later, B\&RI will impact European economies. The B\&RI has the potential to connect Chinese and European markets and production centers, but also to economically tie the European Union, Eastern European Countries, China, the Association of Southeast Asian Nations, the Eurasian Economic Union and perhaps other economic communities in Africa and South America together. The steps taken by Hungary and

$25 \quad$ Marko Nikolić (2017): “Central Eastern European Countries and Serbian Perspective and Position towards Chinese One Belt One Road Initiative - A Geopolitical Overview", http:// www.16plus1-thinktank.com/1/20170830/1496.html (02/02/2018) 
Serbia towards the BBSP are governed by the perceived best interests of both states, they are deeply related to their geo-location, and the clear vision that there is no alternative to interdependency. Chinese interest in the Budapest-BelgradeSkopje-Piraeus corridor is a natural option, based on careful geopolitical analysis. Moreover, the BBSP is a brick belonging to a larger wall, named B\&R, which is a multilevel access strategy, aiming to establish a network of corridors connecting production centers and markets. The BBSP definitively envisages interconnecting the continental and maritime Silk Road within the B\&RI rationale, but cannot, for the time being, be considered an additional economic corridor. The BBSP is the convergence segment between the NELB, the CCWAEC and the MSR. The BBSP is the platform that magnifies the true potential of B\&RI in the Western and central Europe. The BBSP is particularly decisive for landlocked economies, such as Hungary and Serbia. Interestingly, Serbia is located precisely at the heart of this geographic triangle. However, both countries need a common strategy to deal with the opportunities offered by B\&RI. In fact the Magyar Republic is a European Union and a NATO member state, but the Republic of Serbia is not. This could bring additional challenges for both sides. The BBSP is also important to the European Union and to all its members' states, but it must put forward an efficient common strategy that proactively seeks opportunities to maximize mutual benefits. The European Union, and in particular the Central and Eastern European states, have no option but to be geographically bound to be part of B\&RI, having the Greek port of Piraeus as a vital location serving both European and Chinese interests. The European Union needs to balance all different projects in the light of further economic integration. The available options depend very much on the cooperation attitude, on European Union support and less on their ability to bilaterally negotiate advantageous trade and infrastructural asymmetric arrangements. The disputes between Serbia and Hungary over Vojvodina "Hungarian populated" areas, the territorial disputes between Hungary and Slovakia, the statute of Kosovo, and the differences between Hungary and the European Union over the refugees crisis do not help. But the geopolitical narrative is wider than Serbia and Hungary... it is indeed all the role of China in Central and Eastern Europe that is at stake. For Hungary the BBSP could represent an infrastructural anchor which complements the European Union membership and gives the Hungarian people a new beam of hope in terms of economic welfare. For Serbia BBSP is in the middle of strategic options leaning towards a new proximity to the Eurasian Economic Union (EEU), the Shanghai Cooperation Organization (SCO) and its strategic partner China. The BBSP represents an opportunity to put the Central and Eastern Europe back into the geopolitical map.

According to the Chinese way of doing business, the best deal is the one that maximizes the benefits to both parties. As the Chinese saying goes, only when all contribute with firewood, can they build up a strong fire (众人拾柴火 
焰高). The BBSP, the Chinese Balkans corridor, the B\&RI for Western Balkans is filling a geopolitical void, which has the potential to lose the hope for Serbian accession to EU or to reinforce the EU periphery with stronger links. In the same line of reasoning, B\&RI will likely expand to other areas of cooperation, depending on the BBSP implementation success. Therefore, the construction of the BBSP may be an opportunity for both China and the EU. One way or another, the BBSP will be a hallmark Chinese project in the direction of Brussels, a likely result will be a rapprochement between two leading commercial blocks: the European Union and People's Republic of China.

\section{Literature}

- Brunner, Hans-Peter (2013): "What is Economic Corridor Development and What Can It Achieve in Asia's Subregions?", Asian Developing Bank Working Paper Series on Regional Economic Integration, Manila, Philippines, No. 117, 9.

- Carriço, Alexandre (2015): Harmonizando o Poder, Imagem, Diplomacia Pública e Diplomacia Militar da China, Lisboa, Letras Itinerantes.

- Dimitrijević, Duško (2017): “Chinese Investments in Serbia - A Joint Pledge for the Future of the New Silk Road", Institute of International Politics and Economics, Baltic Journal of European Studies, Tallinn University of Technology, Vol. 7, No. 122.

- Eszterhai, Viktor (2017): “The One Belt One Road from Germany's perspective”, http://www.geopolitika.hu/en/2017/08/15/the-one-belt-one-road-from-germanysperspective/(31/08/2018)

- Grubišić, Đurad (2017): "Is it Possible to Use the One Belt One Road Initiatives as a Platform for Cooperation between Chinese and Serbian Small and Middle Enterprises? XVII International Scientific Conference on Industrial Systems, https://www.iim.ftn.uns.ac.rs/is17/papers/93.pdf(31/08/2018)

- International Labour Organization (2004): "Socio-Economic Security Programme - Economic Security for a Better World”, Geneva, International Labour Office.

- Leandro, Francisco José (2018): Steps of Greatness: Geopolitics of OBOR, University of Macau, China.

- Marshall, Tim (2015): Prisoners of Geography, London, Elliot and Thompson Limited.

- Matolcsy, György (2017): "Hungary - A Key State on the Silk Road", Opening Presentation Delivered at the 54th Annual Meeting of Economists on 15 September 2016, http://www.geopolitika.hu/en/2017/03/20/hungary-a-key-state-on-the-silk$\mathrm{road} /(02 / 02 / 2018)$

- Mulenga, Gadzeni (2013): "Developing Economic Corridors in Africa: rationale for the participation of the African Development Bank", AfDB Regional Integration Brief, NEPAD, Regional Integration and Trade Department, No. 1, Tunisia, 2. 
- National Development and Reform Commission and the State Oceanic Administration (2017): "Vision for Maritime Cooperation under the Belt and Road Initiative".

- Nikolić, Marko (2017):“Central Eastern European Countries and Serbian Perspective and Position towards Chinese One Belt One Road Initiative - A Geopolitical Overview", http://www.16plus1-thinktank.com/1/20170830/1496. html (02/02/2018)

- Organisation for Economic Cooperation and Development (2001): "Glossary of Statistical Terms”, http://stats.oecd.org/glossary/detail.asp?ID=303(02/02/2018)

- Stavridis, James (2017): Sea Power: The History and Geopolitics of the World's Oceans, New York, Penguin Press.

- Teokarevic, Jovan (2016):“Serbia: Perspectives on Eurasian integration”, European Council on Foreign Relations, https://www.ecfr.eu/article/essay_eurasian_ integration_serbia(31/08/2018) 


\section{KOMBINOVANJE „POJASA“ SA PUTEVIMA U SRCU EVROPE: GEOPOLITIKA BBSP KORIDORA}

Ovaj rad govori o značaju koridora Budimpešta-Beograd-Skoplje-Pirej (BBSP) u kontekstu inicijative "Jedan put, jedan pojas" (B \& RI), koji povezuje, kao brzi tranzitni put, tri glavna ekonomska koridora. I zaista, čini se da je BBSP platforma koja uvećava pravi potencijal inicijative "Jedan put, jedan pojas» u zapadnoj $i$ centralnoj Evropi. Stoga je BBSP od ključnog značaja za ekonomije zemalja koje ne izlaze na more poput Mađarske i Srbije. BBSP je 'cigla' u većem zidu, kada govorimo o saradnji između Kine i zemalja Centralne i Istočne Evrope. Ali svakako važna cigla, naročito zato što pruža fleksibilnost mreži ekonomskih subjekata. Na kraju, ovaj rad prihvata geopolitičku perspektivu, zasnovanu na geo-ekonomskim konceptima.

Ključne reči: Inicijativa 'jedan pojas, jedan put', Narodna Republika Kina, KOSKO, geopolitika, Srbija, Mađarska, Pirej, Evropa, istočnoevrposke zemlje 